\title{
A POSSIBILIDADE DA CRÍTICA NO CAPITALISMO TARDiO. SOBRE OS REMETENTES E OS DESTINATÁRIOS DA TEORIA CRÍTICA
}

\author{
Amaro Fleck ${ }^{1}$
}

Resumo: De acordo com parte da literatura, a teoria crítica de Adorno é um lamento sobre o fracasso da civilização moderna que é incapaz de dar conta de suas próprias condiçóes de possibilidade. No presente artigo, questiono tal veredito, por meio da análise da questão de como a crítica pode ser feita e de quem seria o destinatário dela, em uma situação de quase completa dominaçáo.

Palavras-Chave: Teoria crítica. Theodor W. Adorno. Capitalismo tardio. Filosofia social contemporânea.

De acordo com grande parte da literatura, Adorno é um pensador resignado, que simplesmente lamenta o fracasso da civilização, e a sua teoria crítica teria sido feita a partir de lugar nenhum, sendo a expressão do inexpressável. Em outras palavras, ela seria algo como uma carta sem remetente, a qual foi escrita a partir de um lugar a que não mais é possível chegar, e também sem destinatário, isto é, teria sido composta em uma linguagem que náo seria mais compreensível. Essa objeção aparece de forma exemplar na seguinte passagem de um livro de Terry Eagleton (1997, p. 52):

\footnotetext{
${ }_{1}^{1}$ Professor de Filosofia da Universidade Federal de Lavras (UFLA), Lavras, MG - Brasil. E-mail: amarofleck@hotmail.com

Doutor em Filosofia pela Universidade Federal de Santa Catarina (UFSC) e Professor de Filosofia da Universidade Federal de Lavras (UFLA). Publicou, entre outros, os artigos: "Resignação? Práxis e política na teoria crítica tardia de Theodor W. Adorno", na Revista Kriterion, em 2017; "Da crítica imanente à crítica do sofrimento, na Ethic@”, em 2016, e "Necessária, mas não suficiente: sobre a função da crítica da economia na teoria crítica tardia de Theodor W. Adorno”, também em 2016, nos Cadernos de Filosofia Alemã.
}

http://dx.doi.org/10.1590/0101-3173.2018.v41n3.08.p145 
Para Herbert Marcuse e Theodor Adorno, a sociedade capitalista definha nas garras de uma reificação que a tudo permeia, desde o fetichismo da mercadoria e os hábitos de fala até a burocracia política e o pensamento tecnológico. Esse monólito inconsútil de uma ideologia dominante é, ao que parece, vazio de contradiçóes - o que significa, com efeito, que Marcuse e Adorno tomam-na por seu valor aparente, julgando-a segundo a aparência que ela desejaria ter. Se a reificação exerce seu domínio em toda parte, então isso presumivelmente deve incluir, para começar, os critérios pelos quais julgamos a reificação - e nesse caso não seríamos de modo algum capazes de identificá-la, e a crítica da recente Escola de Frankfurt torna-se uma impossibilidade. A alienação final seria não saber que estivemos alienados. Caracterizar uma situação como reificada ou alienada é indicar, implicitamente, práticas e possibilidades que sugerem uma alternativa a ela, e que podem assim tornar-se critérios de nossa condição alienada. ${ }^{2}$

Essa citação afirma uma tese, a meu ver, correta: a hipótese da completa reificação, ou alienação é ela mesma não relatável, impossível de ser denunciada, pois, mesmo para ser simplesmente percebida, é preciso ainda haver alguma cisão, contradição ou antagonismo na totalidade social. Só se pode criticar uma determinada situação, se ainda se é capaz de, ao menos por um momento, distanciar-se dela. Mas discordo de que Adorno, em algum momento, tenha defendido a hipótese da completa reificação ou alienação. Trata-se, aqui, de uma caricatura. Este é um termo extremamente pejorativo na academia, mas não vejo motivo para tanto, pois o que uma caricatura faz (ao menos uma boa caricatura) é exagerar alguns traços marcantes. Ainda assim, ela muitas vezes consegue retratar com alguma proeza seu objeto. O que Eagleton faz, nesse trecho, é precisamente isto: ele exagera um traço, mas algo que realmente existe na obra de Adorno. O frankfurtiano de fato assevera que a dominação se disseminou a tal ponto que abrangeu várias instâncias subjetivas, psíquicas. Isso cria uma situação de quase completa reificação e coloca em

\footnotetext{
${ }^{2}$ Essa passagem na obra de Eagleton contradiz um trecho de outra obra dele, publicada apenas um ano antes, $A$ ideologia da estética, em que apresenta um retrato muito mais nuançado da teoria de Adorno. Cito-o: "Adorno é cabalista o suficiente para decifrar os sinais de redenção nos lugares mais improváveis - na paranoia do pensamento-da-identidade, nos mecanismos do valor-de-troca, entre as linhas elípticas de Beckett ou na súbita dissonância de um violino de Schönberg. A história está transbordando de desejo de justiça e bem-estar, clamando pelo dia do juízo, trabalhando para se autoderrubar, plena de poderes messiânicos fracos: basta que se aprenda a procurá-los nos lugares menos óbvios. Mas há sempre uma outra estória. Se Adorno é capaz de decifrar o desejo de felicidade num decreto burocrático, também é depressivamente habilidoso para discernir a rapacidade que se esconde em nossos gestos mais edificantes. Não pode haver verdade sem ideologia, transcendência sem traição, nem benefícios que não sejam comprados à custa da infelicidade do outro." (EAGLETON, 1993, p. 263).
} 
perigo a própria possibilidade da crítica. $\mathrm{O}$ quadro, no entanto, se me permitem a metáfora, não é tão negro como Eagleton sugere, pois haveria ainda, em muitas partes, um cinza escuro, capaz não só de denunciar o negro como de guardar a esperança do colorido.

Embora as questôes de remetente e de destinatário estejam profundamente entrelaçadas e, ao menos no caso da teoria adorniana, todo destinatário é também um possível novo remetente, gostaria de analisá-las em separado, ao menos em um primeiro momento. Começo, portanto, investigando as condiçôes de possibilidade de se fazer a crítica de acordo com o diagnóstico traçado pelo pensador frankfurtiano, isto é, de como seria possível perceber a reificação e denunciar o que a produz, colocando-se, assim, na medida em que isso ainda é possível, fora da totalidade social quase oniabrangente (I); entáo, passo a lidar com o problema de quem seriam as pessoas para quem a crítica é feita (II); por fim, tento resumir minhas principais hipóteses de interpretação e salientar algumas especificidades históricas que são bastante evidentes nesse quesito e que, sem dúvida, influenciaram o diagnóstico adorniano (III).

\section{DAS DIFICULDADES DE AINDA SE SER CRÍTICO}

Antes de passar propriamente à questão de como ainda se pode ser crítico, é conveniente antecipar algumas observaçóes acerca do diagnóstico da sociedade contemporânea feito por Adorno. Apenas para ressaltar que a interpretação feita por Eagleton, no trecho supracitado, segundo a qual a sociedade hodierna seria como um monólito sem fissuras, uma totalidade coesa e fechada, não mais antagônica ou contraditória, dista muito da análise de Adorno. De acordo com o frankfurtiano, a sociedade, apesar de sua crescente integração, segue estando profundamente cindida. A totalidade que caracteriza a presente sociedade é ela própria erigida sobre um antagonismo que se reproduz e se manifesta em cada produto social, em cada fragmento da experiência. Para ele, "nada singular encontra a sua paz no todo náo-pacificado.” (ADORNO, $\mathrm{DN}^{3}$ : 133). Portanto, o mundo está repleto de marcas de tais antagonismos e contradiçôes. Justamente a identidade da situação objetiva e da consciência subjetiva, que seria a condição necessária para uma totalidade coesa e sem fissuras, "se mostra como quebradiça, e [...] no mesmo instante é paga com neurose, com sofrimento, com todos os

\footnotetext{
${ }^{3}$ As citaçôes dos textos de Adorno, para melhor identificação, serão feitas sempre pelas iniciais da obra. No caso específico da Minima moralia, em vez da página, referencia-se o número do aforismo.
} 
possíveis fenômenos de mutilação, assim que se olha apenas um pouco sob a superfície do consentimento feliz." (ADORNO, PETG: 113).

No entanto, como ele afirma na Minima moralia, "faz parte do mecanismo da dominação impedir o conhecimento dos sofrimentos que ela produz.” (ADORNO, MM: \$38). O sofrimento é naturalizado ou interiorizado por aqueles que sofrem, de tal maneira que este raramente é visto como produto de uma ordem social injusta ou irracional. A função do teórico crítico é justamente a de desnaturalizar tal sofrimento. Ele precisa, tal como um estraga-prazeres, "trazer as pessoas à consciência de sua infelicidade" (ADORNO, MM: \$38), mas não simplesmente dizendo para os infelizes que eles são infelizes, caso ainda não o tenham descoberto, mas, sobretudo, mostrando que a causa de suas infelicidades náo está neles mesmos, em suas fraquezas ou deficiências, tampouco em uma ordem imutável à qual se está fadado; a causa de tais sofrimentos reside, ao menos em grande parte, em uma ordem social cujo processo de legitimação é exitoso, na exata medida em que consegue se eximir dos males dela provenientes. A tarefa do crítico é, pois, a de deslegitimar tal ordem social. Cabe a ele mostrar àqueles que sofrem que os seus sofrimentos podem findar ou ser atenuados, se a sociedade for organizada de forma mais justa e racional; se, por exemplo, em vez de se orientar pelo lucro, pelo crescimento econômico desenfreado, ela almejar a satisfação das necessidades vitais e a própria redução do sofrimento.

O problema, porém, é saber: quem ainda conseguiria escapar ao próprio mecanismo de dominação, para conseguir denunciá-lo? Quem teria condições de perceber as marcas do antagonismo e desvendá-lo? E mais: quem ainda teria condiçôes de refletir acerca da denúncia que desvenda o antagonismo? E que critério pode julgar a veridicidade da crítica?

\section{A) $\mathrm{O}$ CRÍTICO}

No aforismo "privilégio da experiência”, na introdução da Dialética negativa, Adorno comenta precisamente sobre aquilo que é aqui investigado. Ele observa que um conhecimento dialético, uma experiência filosófica, precisa de mais sujeito para não definhar, e não de menos sujeito, tal como sugere o espírito positivista de nosso tempo. Uma consequência disso é que tal conhecimento, ou tal experiência, não é possível para todos, mas só para alguns indivíduos privilegiados "por suas disposições e história de vida." (ADORNO, DN: 42). Embora isso soe elitista e antidemocrático, como o próprio frankfurtiano 
reconhece, quem imagina que qualquer pessoa pode fazer tais experiências que são necessárias para a crítica "ignora o que o mundo administrado faz com seus membros forçados.” (ADORNO, DN: 42). E, posteriormente, reforça:

Seria fictício supor que, entre as condiçóes sociais, sobretudo entre as condiçôes sociais da educação, que encurtam, talham sob medida e estropiam multiplamente as forças produtivas espirituais, que com a indigência reinante no domínio da imaginação e nos processos patogênicos da primeira infância diagnosticada pela psicanálise, mas de modo algum realmente transformados por ela, todos poderiam compreender ou mesmo apenas notar tudo. (ADORNO, DN: 42).

Em outras palavras, a dominação é tamanha que chega a ser difícil percebê-la; é tão abrangente, que só poucos conseguem distanciar-se dela o suficiente para conseguir notá-la. Assim, "os únicos que podem se opor espiritualmente a isso são aqueles que esse mundo não modelou completamente." (ADORNO, DN: 42) $)^{4}$. Logo depois, o autor especifica:

Cabe àqueles que, em sua formação espiritual, tiveram a felicidade imerecida de não se adaptar completamente às normas vigentes [...] expor com um esforço moral, por assim dizer por procuraçấo, aquilo que a maioria daqueles em favor dos quais eles o dizem não consegue ver ou se proíbe de ver por respeito à realidade. $\mathrm{O}$ critério do verdadeiro não é a sua comunicabilidade a qualquer um. (ADORNO, DN: 43).

É importante aqui salientar o caráter imerecido do privilégio da incompleta adaptação. Não se trata de críticos que são mais inteligentes, ou que perceberam a reificação por um imenso esforço de pensamento, mas simplesmente de uma questáo de sorte e de privilégio, de terem tido a oportunidade de uma formação espiritual que está em vias de extinção. Ademais, tampouco se trata de críticos que não estão adaptados, que não foram moldados pelo sistema que tudo reifica, porém, de indivíduos que não foram completamente moldados e adaptados. Eles também fazem parte, também reproduzem a má totalidade social e esta também se imiscui em seus pensamentos e em suas

\footnotetext{
${ }^{4}$ Como será visto logo mais adiante, mesmo os indivíduos mais moldados e adaptados à ordem vigente mantêm certo distanciamento, ou, ao menos, precisam lidar com uma série de frustraçóes que colocam em risco tal adaptaçáo completa. Nesse sentido, o indivíduo crítico (aquele que, portanto, pode ser o teórico crítico) se diferencia do indivíduo "comum", por assim dizer, antes por uma questão de gradaçấo em sua capacidade de distanciamento do que por uma questão de sim ou não, de conseguir fazer algo que o outro não consegue (assim, ele é capaz de se distanciar mais, de manter uma reserva maior, frente ao processo de adaptaçấo à sociedade vigente).
} 
críticas. Por isso mesmo, a crítica "precisa prestar contas sobre até que ponto, de acordo com sua possibilidade no interior da ordem estabelecida, está contaminada por essa ordem, e, por fim, pela relação de classes." (ADORNO, DN: 43). Isto é, a teoria só consegue sua independência refletindo e percebendo o quanto está imersa na situação que ela critica. Por causa disso, o frankfurtiano previne as antecipaçóes do que seria uma sociedade correta:

Quem, a fim de escapar da objeção de que não sabe o que quer, pinta para si um estado de coisas justo, não pode abstrair dessa supremacia que se abate mesmo sobre ele. Se sua própria fantasia permitisse imaginar tudo radicalmente transformado, essa fantasia mesma permaneceria ainda acorrentada àquele que imagina e tudo daria errado. No estado de liberdade, mesmo o homem mais crítico possível seria totalmente diverso, exatamente como aqueles para os quais ele deseja a transformação. (ADORNO, DN: 291-292).

Mesmo o crítico está moldado. Não obstante, ele ainda consegue uma distância, embora mínima, que faz com que seja capaz de confrontar-se com tal realidade. Todavia, essa distância não está acessível a todos. Não está acessível mesmo àqueles que, muitas vezes, são os que mais sofrem na situação vigente. Adorno se contrapóe, com isso, tanto a Lukács quanto à maioria do marxismo, por assim dizer, misericordioso. Os trabalhadores e os pobres não estão em melhores condições de perceber quão má é sua situação, simplesmente porque desconhecem qualquer outra. A vida endurecida se interioriza neles, como se fosse algo inevitável. A classe operária só se opôs ao sistema capitalista como tal enquanto estava viva a lembrança de dias diferentes, do mundo pré-capitalista. Depois, lutou só por um melhor quinhão na repartição do produto social, mas não pela transformação da sociedade e do modo de produção. "A crítica ao privilégio transforma-se em privilégio: o curso do mundo é dialético a um tal ponto." (ADORNO, DN: 42). Ou, como salientam outro trecho: "Na linguagem dos oprimidos, porém, resta apenas a expressão da dominação, que também a privou daquela justiça que a palavra autônoma, não-mutilada, promete a todos aqueles que são livres o bastante para dizê-la sem rancor.” (ADORNO, MM: \$65). Tal tese, no entanto, corre o risco de aumentar ainda mais a opressão já vivenciada, na medida em que retira dos oprimidos a própria capacidade de expressar o sofrimento do qual padecem, reforçando o mecanismo de emudecimento social dos menos favorecidos. Pinzani (2011) argumenta, a meu ver com razão, que a teoria crítica precisa ouvir os mais pobres - uma vez que a própria articulação de 
sua situação na linguagem já permite a eles o rompimento ou atenuação de uma dimensão da dominaçáo a qual são submetidos - ao mesmo tempo em que não pode dar crédito total a seus relatos, visto que eles interiorizam as imagens dominantes na sociedade (inclusive e, sobretudo, a imagem que a sociedade tem deles próprios) e ao fato de que sua pobreza impede ou limita a articulação de sua situação (de modo que a autonomia não pode ser pressuposta, sobretudo nos indivíduos em pior situação socioeconômica, pelo contrário, ela precisa ser fomentada). Adorno deu imensa importância aos estudos empíricos conduzidos pelo Instituto (e por ele mesmo, em inúmeras ocasiōes) e sempre foi um entusiasta deles, além de suas obras mais especulativas terem vínculo estreito com tais estudos, apesar de nem sempre explícitos. ${ }^{5}$ Nessa perspectiva, seria injusto acusá-lo de não dar atenção aos diretamente envolvidos e fazer uma crítica externa. Como ele mesmo nota, em passagem já citada, basta olhar com um pouco de atenção para ver quão quebradiço é o consenso feliz e o quanto se manifestam, em todos os lugares, os sofrimentos existentes. Contudo, a teoria crítica adorniana parece dar insuficiente importância ao papel reflexivo dos diretamente concernidos, como se seus relatos apenas indicassem os problemas que precisam ser mais bem diagnosticados pelo teórico crítico.

Assim, a crítica da reificação segue sendo possível, porque ela não é completa, ao menos em alguns indivíduos, os quais tiveram a imerecida sorte de terem ainda uma formação espiritual que não fosse simplesmente talhada sob medida para o mercado, para a função social que a pessoa em questáo provavelmente desempenharia. Isso coloca uma série de questóes. Sendo a crítica um privilégio, como garantir que ela não seja feita visando apenas ao bem do privilegiado? Isso não levaria a uma espécie de paternalismo, no qual um teórico iluminado diz como as pessoas deveriam se comportar?

\footnotetext{
5 Por isso, discordo da afirmação de Honneth, segundo a qual "Adorno mantém ao longo de sua carreira uma atitude ambivalente em relação ao projeto de uma teoria da sociedade interdisciplinar e empiricamente controlada" (HONNETH, 1993, p. 36-7), e que a pesquisa social empírica teria sido cada vez mais marginalizada, no percurso teórico do frankfurtiano (cf. cap. 3). De todos os teóricos vinculados ao Instituto, Adorno provavelmente foi aquele que menos se ateve a uma disciplina (e aquele, por sinal, que mais participou dos estudos empíricos). Seu pensamento se caracteriza, antes, por ignorar as fronteiras entre os diversos âmbitos do conhecimento do que pela tentativa de somar as divisōes do trabalho intelectual estanques em vigor. Como nota Renault (2009, p. 173), o abandono da interdisciplinaridade e da pesquisa empírica, no âmbito da teoria crítica, só ocorre depois de terminada a obra adorniana, com a guinada rumo ao normativismo habermasiano (e, grosso modo, tal abandono se mantém desde então).
} 


\section{B) A bOA CRítica é AQUELA CAPAZ DE EXPLICAR OS FENÔMENOS SOCIAIS}

Tais questóes talvez não encontrem, na obra adorniana, uma resposta conclusiva. Em primeiro lugar, não há garantia alguma de que o privilegiado que teve uma formação melhor não pense, por exemplo, que é capaz de ver os problemas da sociedade por sua maior capacidade e justifique, assim, a hierarquia existente. Nem toda crítica é uma crítica correta. A sociedade capitalista é táo intransparente que mesmo aos olhos do mais agudo crítico tudo aparece obnubilado. As chances de erro, portanto, são sempre grandes, e é preciso precaver-se o tempo todo contra elas.

Porém, há um critério claro que dá fortes indícios sobre a veridicidade da crítica. Sabe-se que a teoria crítica em geral - não apenas em sua versão adorniana, mas também já no escrito programático de Horkheimer, "Teoria tradicional e teoria crítica”, publicado quase trinta anos antes da Dialética negativa - se caracteriza não só pela recusa da não valoração daquilo que ela analisa, quanto igualmente por não separar a crítica, a denúncia, da análise explicativa. Náo se trata de explicar a sociedade, em um primeiro momento, e, em um segundo, criticá-la, mas de fazer uma explicação da sociedade que já é ao mesmo tempo sua crítica. Nesse sentido, o critério de veridição da crítica é sua própria capacidade explicativa. Quanto mais a interpretação crítica da realidade é capaz de explicar os fenômenos sociais, mais ela consegue mostrar o caráter problemático e contraditório destes e mais exige a transformação deles.

Há, portanto, um critério que permite avaliar a crítica, isto é, ver se ela é correta ou não (a saber, seu poder explicativo, sua capacidade de analisar a situação em questáo). O problema levantado há pouco - recordando: se o fato de que se só aqueles que tiveram uma formação espiritual privilegiada seriam capazes de contrapor-se à vida endurecida, mutilada, e denunciá-la, em vez de tomá-la como um fato natural e inevitável, não pode acarretar uma situação na qual a crítica é feita antes com o intuito de manter o privilégio do que de aboli-lo - fica, ao menos em parte, respondido. Não há garantia alguma de que isso não ocorra, contudo, há indícios para julgar que uma crítica que chegue a tais conclusóes fracassa, pois uma teoria crítica que busque a manutenção do privilégio teria, a princípio, mais dificuldades para explicar certos fenômenos, por exemplo, inúmeras patologias que ocorrem nas camadas mais desfavorecidas da população, sem questionar as causas que produzem tais patologias e, assim, demandar a abolição das mesmas. Nesse caso, como nos demais, uma análise aprofundada da situação leva necessariamente ao questionamento das causas que a geram e à exigência da transformaçáo dessas causas. A teoria 
crítica correta não seria uma dentre um leque de possíveis escolhas a se fazer, mas o resultado da análise objetiva da realidade levada até as suas últimas consequências. Algo que Horkheimer já notara, ao afirmar que "qualquer esforço intelectual consequente, preocupado com as questôes humanas, desemboca analogamente na teoria crítica." (HORKHEIMER, 1975, p. 155). A teoria crítica, assim, se faz fiadora da ideia spinoziana de que a verdade é índice de si mesma (ADORNO, DN: 43).

No entanto, é preciso um esclarecimento sobre o conceito de verdade e seu uso, na teoria crítica, especialmente porque os autores vinculados a tal projeto recusam a concepção predominante da verdade como correspondência (a qual afirma, grosso modo, que verdadeira é a sentença que corresponde a um determinado estado de coisas). Adorno (assim como os outros teóricos críticos) adota antes um uso próximo ao hegeliano, de acordo com o qual verdadeiro é a correspondência da coisa com seu conceito (nesse caso, um amigo é verdadeiro, se ele faz aquilo que se espera de um amigo, e falso, se não o faz). ${ }^{6}$ O conceito de verdade, ao menos nessa acepção, possui valor normativo: "No conceito enfático da verdade está inclusa a correta ordenação da sociedade." (ADORNO, SLCS: 60). Não se trata, porém, de contrastar a ideia de uma sociedade correta com a sociedade existente, pois tal ideia só "surge da crítica, portanto da consciência da sociedade quanto a suas contradiçóes e necessidades." (ADORNO, SLCS: 57). A própria verdade tem um cerne somático, ao menos segundo o frankfurtiano, pois, em última instância, ela consiste na negação do sofrimento, no clamor de sua abolição.

A teoria crítica fica, assim, em uma posição bastante frágil. Ela precisa convencer aqueles que levam uma vida lesada de que a causa de seus sofrimentos está na ordem social e de que é possível transformá-la, todavia, para tanto, ela se defronta, por um lado, com discursos que ajudam a legitimar a ordem, que reforçam os mecanismos de dominação e, por outro, com discursos críticos que elegem "bodes expiatórios" e cujas soluçôes podem ser ainda piores do que os males a remediar. É quase desnecessário dizer que não há garantia alguma de que obterá sucesso em tal empreitada. Em primeiro lugar, o seu

\footnotetext{
${ }^{6}$ Nas próprias palavras de Hegel: "Um verdadeiro amigo; e se entende com isso, um amigo cuja maneira-de-agir é conforme ao conceito de amizade; igualmente se fala de uma verdadeira obra-de-arte. Não-verdadeiro, entáo, quer dizer o mesmo que mau, inadequado em si mesmo. Nesse sentido, um mau Estado é um Estado não-verdadeiro, e o mau e o não-verdadeiro, em geral, consistem na contradiçấo que tem lugar entre a determinação ou o conceito, e a existência de um objeto. Podemos fazer uma representação correta de um tal objeto mau, porém o conteúdo dessa representação é algo em si não-verdadeiro." (HEGEL, 1995, p. 82).
} 
discurso carece da formação, que está em grande medida ausente para poder ser compreendido (ao passo que o discurso que elege "bodes expiatórios" aumenta as chances de êxito em condições de pior formação). Mesmo para julgar a teoria crítica como a melhor explicação de dado fenômeno já é preciso ter sido um privilegiado, gozar de uma educação que não foi oferecida a todos. ${ }^{7}$ Além disso, a objetividade à qual a teoria apela é fugaz: ela pretende explicar os fenômenos com base em sua observação atenta e em sua análise mais rigorosa possível, mas sabe que a promessa de certeza oferecida pelo positivismo é uma quimera e, por conseguinte, não a repete.

\section{C) Alienados ou reificados? Sobre o problema do paternalismo.}

No entanto, resta a dúvida acerca do possível paternalismo da teoria crítica. Objeta-se, com isso, que a teoria crítica (a qual denunciaria a alienação das pessoas que estão, em geral, conformadas com a sua situaçáo) coloca-se a si mesma em um pedestal privilegiado e arroga-se uma postura de mestre, outorgando a si própria a função de ensinar aos indivíduos alienados o que seria a vida correta, muitas vezes contra a manifesta vontade das próprias pessoas. Mais precisamente, aqui seria o caso de que o indivíduo, o qual, de forma imerecida, teve o privilégio da formação espiritual e que, por causa disso, não foi talhado sob medida para a mera reprodução do existente, seria paternalista ao dizer para aqueles que, em sua visão, estão completamente moldados, adaptados, que eles vivem uma "vida falsa", mesmo que tenham optado por ela. Este é um assunto deveras atribulado e exige um bocado de cautela. Existe hoje um quase consenso liberal-democrático (quiçá pós-moderno) que advoga pelo igual valor de todas as opinióes e escolhas, o qual, no mínimo, pressupóe certo grau de autonomia bastante desenvolvido nos indivíduos. Esse quase consenso condena como autoritária toda conduta que, como é o caso da teoria crítica, não consiste em simplesmente corroborar tais opinióes e escolhas. No que segue, gostaria de comentar porque, em minha visão, a teoria crítica não incorre nem no erro do autoritarismo nem no do paternalismo, a partir da

\footnotetext{
7 Zuidervaart (2007, p. 66-70) observa que, para Adorno, a experiência filosófica se autentica a si mesma, e critica o teórico frankfurtiano, por não articular contextos de justificaçăo em que a concepção de verdade pudesse ser publicamente testável. De fato, não há tal porto seguro, no pensamento adorniano. Talvez se pudesse dizer que, se as pessoas náo fossem lesadas, tanto em suas vidas quanto em suas capacidades cognitivas, elas poderiam chegar a um acordo sobre a verdade, mas isso de nada adiantaria para lidar com a situação, que, aos olhos do frankfurtiano, importa: uma situação em que as pessoas são lesadas e em que o mecanismo de dominação mascara até mesmo os sofrimentos que a dominaçăo causa.
} 
diferenciação da crítica da reificação frente à crítica da alienação e da discussão acerca da função social do teórico crítico.

Em primeiro lugar, há que se questionar se os termos "reificação" e "alienação" podem ser tomados como sinônimos, como foi o caso na passagem supracitada de Eagleton. Penso que não. Aliás, não só os dois termos não são sinônimos, como Adorno faz menção de suas diferenças e explica porque adota um e recusa o outro. Alienação remete em especial às obras do jovem Marx (o termo é também usado por Hegel, porém, em um sentido bastante distinto), sobretudo aos Manuscritos econômico-filosóficos, e à tese nelas contida segundo a qual o homem se encontra alienado de sua própria natureza, na sociedade capitalista, porque não é mais o dono dos produtos de seu trabalho, tese esta que alude a um passado em que o fenômeno da alienação não ocorre, uma vez que os homens eram os donos imediatos daquilo que faziam. Para Adorno, essa tese é problemática:

Os homens, sem nenhuma exceçáo, ainda não são de maneira alguma eles mesmos. Com toda a razáo, poder-se-ia pensar com o conceito de si próprio a sua possibilidade, e essa possibilidade se opóe de modo polêmico à realidade do si próprio. É exatamente por isso que o discurso sobre a alienação do eu é insustentável. Apesar de seus melhores dias hegelianos e marxistas, ou mesmo por causa deles, esse discurso se tornou apologético porque dá a entender, com facetas paternais, que o homem seria separado de um ser-em-si que ele sempre foi, por mais que ele nunca tenha sido, e que, por consequência, recorrendo às suas ả $\rho \chi \alpha u$, ele não pode esperar nada que se submeta a uma autoridade, àquilo que justamente lhe é estranho. $\mathrm{O}$ fato de esse conceito náo figurar mais em $O$ capital de Marx não é apenas condicionado pela temática econômica da obra, mas possui um sentido filosófico. (ADORNO, DN: 232).

Como fica claro nessa citação, para Adorno, a tese da alienação é simplesmente "insustentável". Ela dá a entender que a essência humana era realizada em formaçôes sociais anteriores e deixou de sê-la, o que é falso. Não há uma boa natureza original à qual se possa recorrer, para denunciar o estado atual do mundo, porque, na visão de Adorno, a história foi até agora pré-história, a história da cegueira, do fetichismo, da superstição. Não adianta contrapor a sociedade capitalista com as formações sociais anteriores, pois elas eram igualmente más e problemáticas (o frankfurtiano, por sinal, jocosamente observa que "as caracterizaçóes contemporâneas das cidades medievais costumam dar a impressão de que uma execução tinha lugar 
expressamente para o divertimento do povo.") (ADORNO, DN: 164). A emancipação pretendida não é de forma alguma o retorno a uma situação passada, como o romantismo advoga. Além disso, também essa ideia de unidade consigo mesmo, de não estranhamento ou não alienação como algo bom, é problemática para o frankfurtiano:

Para além do romantismo que se experimentou como mal do século, como sofrimento com a alienação, levanta-se a expressão de Eichendorff: "bela estrangeiridade". A disposição reconciliada não anexaria o estranho a um imperialismo filosófico, mas encontraria sua felicidade no fato de o estranho e o diverso permanecerem na proximidade por nós conferida, para além do heterogêneo tanto quanto do próprio. (ADORNO, DN: 164).

Trata-se antes de uma reconciliação com o diverso, não de uma transformação deste em familiar. A alienação, tornar-se outra coisa do que aquilo que seria a sua "real" natureza, por conseguinte, sequer é algo problemático. Como ideal de condiçấo emancipada é, assim, mais interessante a ideia eichendorffiana de uma "bela estrangeiridade" do que tal concepção de que o bom é o original, o autóctone, o primeiro.

O próprio Adorno assevera que a crítica da alienação tem "facetas paternais", pois consiste em criticar uma determinada situação a partir de um modelo arbitrário de realização, a verdadeira natureza. Entretanto, o mesmo não vale para o termo reificação. Dizer que algo está reificado significa, simplesmente, que esse algo se tornou uma coisa. Portanto, só faz sentido criticar a reificação daquilo que não era ou não devia ser um objeto, mas sim um sujeito. A crítica da reificação remete igualmente à obra de Marx, mas, sobretudo, à sua obra tardia, em especial à tese segundo a qual a opacidade produzida pelo fetichismo da mercadoria faz com que as relaçóes pessoais se objetifiquem e deixem de ser controladas pelas pessoas, tornando-se, com isso, um autômato, o capital. Nesse caso, nas palavras de Marx, o "valor se torna aqui o sujeito de um processo em que ele [...] se autovaloriza.” (MARX, 1985, p. 130). O importante a notar é que ele é o próprio agente do processo, ao passo que as pessoas participam no mesmo meramente como engrenagens, como meios pelos quais o valor alcança seu objetivo.

O termo reificação, porém, é comumente associado à teoria do Lukács de História e consciência de classe, que se distingue fortemente do emprego marxiano do termo. Se a reificaçáo é algo objetivo aos olhos de Marx (as pessoas tornam-se coisas e as coisas tornam-se sujeitos), ela é principalmente subjetiva 
para Lukács (é a consciência que está reificada). Se Adorno recusa, de forma veemente, o termo alienação, ele é ambíguo quanto ao conceito de reificação. Penso que ele se aproxima do uso marxiano e mantém reservas maiores com o emprego lukácsiano. Mesmo assim, ele sempre recusa a crítica da reificação como uma crítica que faz apelo a uma situação passada em que tal fenômeno ainda não se dava. ${ }^{8}$ Objetivamente (por conseguinte, na acepção marxiana), o termo é adequado para tratar da condição dos humanos, na sociedade atual: eles são antes os objetos da sociedade do que os seus sujeitos. Enquanto tal, a crítica da reificação aponta para a inexistência da autonomia, da autodeterminaçâo. Se os indivíduos são apenas engrenagens no processo social, a liberdade deles é ilusória, assim como as suas escolhas.

A crítica da reificação, ao contrário da crítica da alienação, não corre o risco de ser paternalista. Adorno náo critica o indivíduo, por ele preferir a vida falsa à vida correta, mas critica a situação social, por ela impor um modelo de vida sobre o indivíduo, por ela não permitir que as pessoas se autodeterminem. Nesse sentido, a teoria crítica pode muitas vezes mostrar como é ilusória a crença de que as pessoas são o resultado de suas escolhas, de suas preferências e, portanto, responsáveis pela sua situação atual; ela evidencia como mesmo as escolhas são forçadas, predeterminadas: a opiniâo dominante "adora apresentar alternativas entre as quais se deve escolher, uma das quais se deve marcar com uma cruz. [...] Ao pensamento filosófico, porém, em suas situaçóes essenciais, cabe não jogar esse jogo. A alternativa previamente dada já é um fragmento de heteronomia." (ADORNO, DN: 35). Pode-se retrucar que ainda isto, a denúncia da falta de autonomia, é paternalismo, que as pessoas preferem ser engrenagens, no entanto, nesse aspecto, há que se perguntar o que significa esse preferir. Adaptar-se ao inevitável é um mecanismo de autopreservação, muitas vezes necessário; o que a teoria crítica faz é demonstrar que muito do que se apresenta como inevitável na verdade não o é, que poderia ser transformado.

O próprio Adorno, todavia, sugere que a crítica não deve focar no fenômeno da reificação: "O lamento sobre a reificação evita mais do que denuncia aquilo que produz o sofrimento dos homens. O mal está nas relações que condenam os homens à impotência e à apatia, e que, no entanto, teriam de

${ }^{8}$ Criticando Heidegger, Adorno comenta que "a necessidade filosófica passou sem ser percebida da necessidade de conteúdo coisal e de solidez para a necessidade de escapar da reificaçáo no espírito, realizada pela sociedade e ditada categorialmente para os seus membros, por meio de uma metafísica que condena uma tal reificação, indicando-lhe os seus limites por meio de um apelo a algo originário imperdível." (ADORNO, DN: 84). 
ser alterada por eles; e não primariamente nos homens e no modo como as relaçóes aparecem para eles." (ADORNO, DN: 163). Isto é, a crítica deve destacar aquilo que reifica as pessoas, em vez de afirmar que elas estáo reificadas. "A consciência, reificada na sociedade já constituída, não é seu constituinte." (ADORNO, DN: 163). A reificação é, por assim dizer, um sintoma do problema, mas não o próprio problema. ${ }^{9}$ Mais ainda, Adorno se distancia do uso lukácsiano de reificação, predominantemente subjetivo, por não acreditar que seja possível uma consciência correta nessa situação social (como seria o caso, em História e consciência de classe, do ponto de vista do proletariado): "Assim como não há uma vida correta no falso, tampouco pode haver uma consciência correta nele." (ADORNO, MWG: 591).

Por fim, gostaria ainda de fazer uma observaçáo sobre a crítica ao paternalismo. É evidente que nenhum teórico crítico se coloca na função de rei-filósofo, náo cabendo a ele decretar como a sociedade será organizada, sequer elaborar um plano a ser simplesmente ratificado pelas pessoas. Nesse sentido, acho que toda a crítica ao paternalismo está, grosso modo, mal colocada, pois não leva em conta a função social do crítico. Ele não é o pai ou governante que decide o que se pode ou não fazer, nem mesmo o tutor que ensina a criança a educar seu gosto. Antes, é aquele que confronta a sociedade com os próprios critérios dela, que rememora algumas das promessas não cumpridas da própria ordenação social e que analisa as patologias, em busca de suas causas. Assim, o crítico não está nunca em uma situação de poder, porém, sempre na posição daquele que exige mudanças, embora não seja ele próprio o agente de tais transformaçôes (pode até participar delas, mas a sua principal função é fomentá-las). Ora, cabe a ele, de fato, mostrar como e porque muitas relaçóes que as pessoas não tomam como problemáticas o são. Nesse caso, é preciso confrontar as opinióes dominantes e não as corroborar. Não por estar em um pedestal que tornaria a sua visão correta e as demais erradas, como os críticos do paternalismo costumam objetar, no entanto, argumentando e apontando às pessoas evidências e indícios que elas até então não teriam percebido. En-

9 Zuidervaart nota igualmente a função apenas secundária do conceito de reificação, na obra adorniana. Cito-o: "Adorno chamou a reificaçâo da consciência um 'epifenômeno'. O assunto com o qual uma teoria social crítica realmente precisa lidar é por que a fome, a pobreza, e outras formas de sofrimento humano persistem apesar do potencial científico e tecnológico para mitigá-las ou eliminálas." (ZUIDERVAART, 2011). 
fim, o teórico crítico, por mais que o queira, não está em condições de obrigar alguém a ser maior de idade. ${ }^{10}$

\section{DAS DIFICULDADES DE AINDA SE TER PÚBLICO}

Tendo-se visto quem é o crítico, o teórico capaz de ainda se distanciar o bastante da situação vigente para denunciar as suas mazelas e contradiçôes, resta analisar qual o seu público-alvo. Segundo a interpretação aqui proposta, a teoria crítica de Adorno considera que as possibilidades para a emancipação não estavam dadas, no momento em que ele escreveu e teorizou. Isso não leva a um recolhimento teórico resignado, mas antes a um engajamento em tarefas de resistência, na tentativa de transformação de fatores subjetivos e melhorias dentro da ordem existente, ao menos até que as precondiçôes para uma transformação emancipatória voltem a estar presentes. ${ }^{11}$ Seu público-alvo, por conseguinte, deve ser também alguém capaz de, mesmo que apenas futuramente, transformar a sociedade. Isso significa que se trata, aqui, de um possível sujeito revolucionário, tal como fora o proletariado, no começo do século XIX. Para o frankfurtiano, contudo, o proletariado está então completamente integrado à sociedade, não é mais uma força hostil a ela e nem dá mostras de que poderia voltar a ser. Adorno tampouco credita ao lumpemproletariado, à ralé ou à plebe, alguma capacidade transformadora, até mesmo porque, nos anos sessenta, em especial na

\footnotetext{
${ }^{10}$ Pode-se objetar que tal teoria crítica, embora não implique num paternalismo político, resulte mesmo assim num paternalismo epistêmico, ao ver patologias que não são sentidas como tais pelos sujeitos diretamente envolvidos. É o caso, para mencionar um exemplo, do antissemita ou do homofóbico, que são considerados por tal teoria crítica como indivíduos patológicos, embora eles próprios não se vejam como tais - ao contrário, a patologia, para eles, estaria presente antes nos judeus ou nos homossexuais. Nesse caso, não vejo como uma teoria possa permanecer crítica sem certo grau de paternalismo epistêmico. Uma teoria que se coloque em grau de igualdade com os diretamente envolvidos pode apenas corroborar a compreensão mundana destes, reforçar suas intuiçóes pré-teóricas, todavia, não as transformar. Outra objeçẫo seria a de que tal teoria crítica criaria patologias de antemão, consideraria patológicos os indivíduos simplesmente por eles não se adequarem aos seus critérios de sanidade. Uma teoria crítica que fizesse isso estaria, evidentemente, equivocada. Ela sempre parte da constataçáo do sofrimento, do mal-estar, da violência, e vai em busca de suas causas, nunca de um ideal prévio. No caso do homofóbico ou do antissemita, ela deve partir da constatação de que tais indivíduos apresentam um comportamento violento, antissocial, e perceber as contradiçóes de seus discursos e procederes, alertando o restante da sociedade para o perigo iminente a tais atitudes e sugerindo medidas para precaver a disseminaçáo delas.

${ }^{11} \mathrm{O}$ diagnóstico de Adorno, assim como a questâo relativa ao engajamento político e à práxis transformadora que seria então possível, é assunto do primeiro capítulo de minha tese de doutorado (FLECK, 2015). Tal assunto recebe tratamento acurado em Juárez (2012) e Freyenhagen (2014).
} 
Europa, também ele estava integrado ou era quase inexistente. Tampouco poderiam ser os estudantes ou a juventude tal sujeito. $\mathrm{Na}$ verdade, em sua visão, não parece haver qualquer indício de um grupo social capaz de opor alguma resistência organizada ao sistema capitalista. Isso não faz com que ele adote uma variante de pensamento mágico que pense que a transformação possa se dar sem um ou mais grupos sociais que a proponham, exijam e lutem por ela. Muito menos que adote a ideia de que certas instituiçôes sociais, como o direito ou a democracia, teriam em si algum potencial emancipatório que bastaria desenvolver. ${ }^{12}$ Tais instituiçóes têm servido, sobretudo, à reprodução da ordem existente, e apelar para supostos aspectos contrafatuais os quais lhes seriam intrínsecos pode parecer tão dogmático quanto o velho comunista que segue achando que, apesar de todos os indícios apontarem para o contrário, o proletariado está ganhando consciência e, quando menos se espera, fará a revolução.

No que segue, argumento que Adorno pensa concomitantemente em dois destinatários distintos: as geraçóes futuras, capazes de engajarem-se em uma transformação radical e verdadeiramente emancipatória da sociedade, quando as condiçóes assim o permitirem; e os indivíduos da sociedade atual, na medida em que não estão plenamente adaptados à sociedade e podem, por isso, promover melhorias (não emancipatórias) dentro da situação vigente e colaborar, na medida do possível, para a criação das precondiçôes necessárias para uma maior transformação futura.

\section{A) Geraçóes futuras}

O primeiro destinatário da teoria crítica são as geraçóes futuras. Uma vez que a emancipação estava bloqueada, cabia à teoria crítica salvaguardar a ideia de liberdade para um momento em que esta pudesse novamente se realizar. Trata-se, aqui, da ideia da teoria crítica como garrafas jogadas ao mar, na esperança de que alguém posteriormente as recolha e faça bom uso delas. ${ }^{13} \mathrm{E}$,

$12 \mathrm{O}$ que não significa, obviamente, que Adorno seja contra a democracia ou o direito, ou que não acreditasse que esse era o sistema político e jurídico mais adequado para a sociedade em que vivia. Apenas significa que ele não acreditava que a democracia pudesse emancipar as pessoas de sua condição de objetos, de engrenagens. Direito e democracia podem acarretar, em sua visão, melhorias dentro da ordem existente, mas são demasiado limitados para conseguir tornar tal ordem justa, correta e racional.

13 "O lugar do trabalho crítico e persistente é aqui e agora, mesmo quando nẫo há à vista destinatário para o que se tem a dizer. Adorno não se dirige a ninguém definido: classe, organização, movimento, 
especialmente, uma ideia de resistência: manter vivo o ideal de uma sociedade verdadeira, justa e emancipada em um momento em que até mesmo tal ideal corre perigo de desaparição. Não obstante, só faz sentido manter vivo tal ideal por se cogitar que, em dias melhores, ele possa ser realizado. Foi visto que, segundo Adorno, o sistema capitalista segue sendo antagônico e contraditório. Embora reconheça que a economia social de mercado foi capaz de atenuar os antagonismos sociais e que o modelo econômico intervencionista, de tipo keynesiano, consegue instituir de antemáo mecanismos que evitem ou amenizem as crises (ADORNO, PETG: 50-2), ele pensa que o capitalismo continua tendo tendências problemáticas (por exemplo, em direção à formação de monopólios cada vez maiores), as quais, em algum momento, devem explodir ou ultrapassar os limites em que são toleradas. Não cabe à teoria crítica, ao menos em sua versão adorniana, fazer prognósticos econômicos, mas a sua própria afirmação de que o modo de produção capitalista não tem encontrado objetivamente obstáculos para a sua reprodução tem também validade histórica. "Do jeito que o mundo vai, hoje ou amanhã podem surgir situaçôes que, embora sejam muito provavelmente catastróficas, ao mesmo tempo restauram a possibilidade de ação prática que está hoje obstruída." (ADORNO, apud WIGGERSHAUS, 1995, p. 566).

Uma crise do capitalismo, por exemplo, pode excluir uma parcela considerável da população e criar nela um potencial transformador ou hostil à reprodução de tal sistema. Uma crise ecológica pode minar as condiçôes de reprodução da vida nos padróes atuais e obrigar a uma mudança súbita para um modelo radicalmente distinto. Até mesmo uma situação de contínua prosperidade, como a vivida na época, ao menos na sociedade alemã, poderia conduzir a uma melhoria de vida que, entre outras coisas, fizesse com que as pessoas aumentassem as suas expectativas e exigências. Como será visto mais adiante, no presente estudo, Adorno critica aqueles que pensam que, quanto mais piora a situação, melhoram as chances de mudança, pois um dos pré-requisitos para uma transformação emancipatória é justamente um entendimento autônomo e independente que só se faz possível com certa espécie de liberdade das necessidades imediatas mais prementes (ADORNO, PETG: 104-105). O fato, portanto, de que as precondiçóes objetivas de uma transformação emancipatória não estivessem mais presentes não deve ser interpretado como um destino duradouro, mas como algo que, quando menos se espera, pode

partido. Para usar uma imagem que lhe era clara, trata-se de, como um náufrago, lançar ao mar garrafas com bilhetes, sem prejulgar o resultado, mas, sobretudo, sem esmorecer." (COHN, 1986, p. 24-25). 
deixar de ser válido. É certo que os dois fatores os quais, na visão de Adorno, impedem a possibilidade de emancipação - a saber: a ausência de uma classe organizada antagonista e a intensificação da dominação, em especial por meio de sua interiorização (o fato de o sistema dominar cada vez mais as próprias instâncias psíquicas dos indivíduos) - são estruturais e quase impossíveis de serem removidos.

Todavia, aqui pode ter vigência igualmente o "conselho de precaução" de Marx, segundo o qual tudo o que aparenta ser sólido e estável na sociedade burguesa pode, como num passe de mágica, se desmanchar no ar. Acima de tudo, é o capitalismo que enfrenta continuamente uma tensão criada pela necessidade de engajar, de forma permanente, as pessoas em seus mecanismos e, ao mesmo tempo, frustrar as expectativas de tais pessoas, ao não realizar as promessas que faz (de riqueza material, de satisfação das necessidades etc.).

\section{B) INDIVÍDUOS NÁO PLENAMENTE ADAPTADOS}

A teoria crítica de Adorno, entretanto, não é endereçada apenas às gerações futuras, tampouco almeja só uma transformação emancipatória. Como venho argumentando, embora uma ordem correta das coisas não estivesse no horizonte das possibilidades, ao menos de acordo com o frankfurtiano, disso não decorre uma aceitação resignada do existente. Muito pelo contrário, tal diagnóstico implica um engajamento em práticas que, apesar de não propriamente emancipatórias, consigam transformar o mundo em algo menos hostil, menos falso. A despeito de uma libertação dos obstáculos que impedem a emancipação estar por ora descartada, há inúmeras lutas que podem ser travadas e melhorias que podem ser conquistadas dentro deste estado de náo liberdade. Se a teoria crítica, como foi visto no primeiro tópico, se engaja na luta por tais melhorias, ela precisa, portanto, ter também um destinatário que já esteja presente na atual sociedade. Designo tal destinatário como "indivíduos não plenamente adaptados”, mas isso logo exige algumas especificaçôes.

Em primeiro lugar, pode-se abordar uma tendência (bem diagnosticada por Adorno) geral de crescimento do fator adaptativo. Como as pessoas são incapazes de transformar, precisamente por sua falta de liberdade, a situação social em que vivem, elas tendem cada vez mais a se adaptar a ela. ${ }^{14}$ Aliás,

\footnotetext{
${ }^{14}$ Evidentemente, mesmo em uma sociedade liberta, as pessoas também precisam se adaptar à sociedade, mas isso ocorreria de forma muito distinta. Em primeiro lugar, porque seria um processo de máo dupla: tanto a pessoa se adapta à situaçăo quanto esta é transformada por ela (portanto, adapta-se
} 
isto é simplesmente uma necessidade, elas precisam se adaptar. Contudo, elas podem fazer isso de forma crítica, mantendo certo distanciamento e mesmo oposição, quiçá até resistência, ou podem, ao contrário, buscar se identificar com a situação social e mesmo ver o inevitável como se fosse uma escolha sua, fazendo da necessidade virtude. Isso, evidentemente, é uma questão de gradação. Pode-se ser mais ou menos adaptado à situação social. Para Adorno, é impossível se estar nos extremos: não se adaptar em nada a ela, tampouco se adaptar completamente. Mesmo o mais completo pária não sobreviveria na sociedade em completa oposição a ela, porque até em suas instâncias psíquicas mais profundas ele precisa, ao menos em parte, se adequar, se endurecer. O contrário é que pode surpreender. A afirmação de que ninguém se adapta completamente parece contrariar boa parte das observaçóes feitas sobre a teoria adorniana, mas isto é, de fato, o que ele sustenta:

Pois nas próprias necessidades dos homens catalogados e administrados há algo que reage naquilo em que eles não estão completamente controlados, o excedente da parcela subjetiva da qual o sistema não se assenhoreou completamente. As necessidades materiais precisam ser respeitadas mesmo em sua figura invertida, causada pela superprodução. (ADORNO, DN: 86).

Essa passagem explicita certo limite mesmo à dominação quase onipotente: os indivíduos têm necessidades corporais que náo podem ser moldadas a bel-prazer. Pelo contrário, elas exigem sua satisfação e provocam reaçôes de descontentamento, quando frustradas. Em outra passagem, o frankfurtiano é ainda mais enfático:

Por conseguinte, o que a indústria cultural apresenta às pessoas em seu tempo livre é, se minhas conclusóes não são precipitadas, sem dúvida consumido e aceito, mas com uma espécie de reserva, de forma parecida a como também os ingênuos não aceitam como simplesmente verdadeiros os acontecimentos do teatro ou do filme. Talvez ainda mais: náo se acredita inteiramente neles. A completa integração da consciência e do tempo livre evidentemente náo está bem realizada. Os interesses reais dos indivíduos ainda são bastante fortes para resistir, no limite, ao confinamento (Erfassung) total. Isto concordaria com o prognóstico social de que uma sociedade cujas contradiçóes fundamentais persistem inalteradas não pode tornar-se totalmente integrada sequer na consciência. (ADORNO, Fr: 654-655).

a ela), embora em menor medida. No capitalismo tardio, no entanto, as pessoas são cada vez mais impotentes, o que significa que esse processo, em vez de ser de mão dupla, é praticamente unilateral, e a situação social é assim imposta aos indivíduos sem que estes possam transformá-la, mesmo nos seus menores detalhes. 
Isto é, apesar de tudo, as pessoas mantêm um distanciamento frente àquilo que assistem ou consomem, uma espécie de reserva que pode ser maior ou menor. Aqui se abre um campo, por conseguinte, no qual a teoria crítica pode atuar. Ela deve ser capaz de fomentar nos indivíduos as instâncias críticas que permitam a eles se distanciarem mesmo em seu contínuo processo de adaptação. Para tanto, precisa se engajar no processo de educação e ilustração da sociedade, processo este que, contra as tendências dominantes na sociedade atual, pode ser capaz de fortalecer o que resta de independência e autonomia nas pessoas (ADORNO, EnA: 690).

Mas aqui é importante, novamente, delimitar claramente o campo do que seria possível para Adorno, ao menos segundo minha interpretação. Minha hipótese é de que a teoria crítica adorniana tem duplo objetivo: por um lado, a desbarbarização da sociedade, um processo que pode e precisa ser feito imediatamente e que é realizado, sobretudo, pela educação e pelo esclarecimento, os quais aumentam a capacidade de reflexão crítica dos indivíduos e, portanto, sua aptidão para lidarem de forma mais distanciada com a totalidade social e sua adaptação a ela; por outro, a efetiva emancipação, a qual significa cabalmente a conquista da autonomia pelas pessoas por meio da abolição do processo que as subjuga, que as torna meras engrenagens, a saber, o modo capitalista de reprodução social, abolição esta que não pode, pois, ter êxito, e que, portanto, deveria ser encampada por geraçóes futuras, em um momento no qual a conjuntura fosse diferente. Resta saber até que ponto a própria desbarbarização da sociedade já é um passo rumo à emancipação ou, melhor, um meio de criar as precondiçóes necessárias para ela. Penso que a desbarbarização é um passo importante, necessário, para se criar as precondiçóes de uma mudança consciente na ordem social; no entanto, só isso não é o suficiente, é preciso contar com a possibilidade de uma crise ou situação em que a própria ordem social mostre suas fragilidades.

\section{Conclusấo: Os maus bocados de UM CRítico EM UMa SituaÇão de PROSPERIDADE}

É bastante provável que, dentre os distintos pontos da crítica social adorniana, este - a questão do remetente e do destinatário - seja, por assim dizer, um dos mais datados. Ao menos um daqueles que precisa de mais contextualização histórica, para ser compreendido. Isso por um motivo muito 
simples: Adorno escreve sua obra tardia, no decorrer de um processo de grande prosperidade econômica, o qual pode até ser considerado inclusivo, pois, em especial na Alemanha, realmente elevou o padrão de vida mesmo das camadas mais pobres em um nível considerável. Os períodos de prosperidade costumam ser, também, momentos de comodismo ou, ao menos, de integração. Isso criou uma espécie de sombra que paira sobre a obra adorniana, a qual consiste no temor de o capitalismo conseguir administrar de forma permanente as suas tensóes e contradiçóes, a tal ponto que consiga manter as pessoas subjugadas, porém, mesmo assim, não hostis ao processo que as subjuga. Um pouco como na obra beckettiana: o pior parece não ser a efetiva possibilidade do fim de partida, da catástrofe total, mas sim a perpetuação da agonia, do estado de espera em que ficam os indivíduos reduzidos ao estado de espectadores passivos de sua própria desgraça, ainda que cômoda. Mais ainda, mesmo a situação de prosperidade não teria conseguido, aos olhos do frankfurtiano, afastar de vez as possibilidades de recaída na selvageria que marcara de forma indelével não só a sociedade alemâ, mas também a sociedade moderna em geral. De qualquer forma, o tempo no qual Adorno escreve sua obra tardia contrasta fortemente com nossa época, marcada pela rápida deterioração do padrão de vida, causada por crises como a do capitalismo e a ecológica ou climática. Antes de concluir, gostaria ainda de mencionar outra vez que um pensamento datado não é, por isso, menos interessante. Mau é o pensamento que já surge obsoleto ou, ainda, aquele que conquista sua permanência ao custo de sua abstração.

Enfim, para recapitular, no presente artigo, afirmei que, segundo o autor frankfurtiano: 1) a possibilidade da crítica permanece aberta, na medida em que continua havendo indivíduos náo totalmente modelados pela sociedade; 2) a crítica feita por eles é correta, na medida em que é capaz de explicar a sociedade e suas patologias; 3 ) tal crítica não é paternalista (ao menos no sentido político), principalmente porque ela não consiste em dizer que as pessoas são alienadas e, portanto, não vivem do modo certo, mas sim por criticar o processo de reificação que impede que essas pessoas se autodeterminem; 4) ela é endereçada às geraçôes futuras, uma vez que estas podem dar fim ao processo de reificação, em um momento que se mostrar oportuno (diferente, portanto, do contemporâneo a Adorno); 5) ela é também endereçada aos indivíduos da sociedade que lhe foi presente, na medida em que eles não estáo plenamente adaptados e que se pode fomentar a capacidade crítica destes, resistindo assim contra a barbarização da sociedade. 
FLECK, A. The possibility of critique in late capitalism: on sender and addressee in Adorno's late critical theory. Trans/form/açāo, Marília, v. 41, n. 3, p. 145-168, Jul./Set., 2018.

ABSTRACT: According to a certain part of the relevant literature, Adorno's critical theory is a lament on the failure of modern civilization to explain its own conditions of possibility. In this paper, I question this verdict by analyzing the problem of how criticism can be done and who the addressee (audience) for it would be in a situation of almost complete domination.

KEYwords: Critical theory; Theodor W. Adorno; Late capitalism; Contemporary social philosophy.

\section{REFERÊNCIAS}

ADORNO, T. W. (SLCS). Sobre a lógica das ciências sociais. In: COHN, G. (Ed.). Theodor W. Adorno: sociologia. São Paulo: Ática, 1986.

. (MWG). Meinung Wahn Gesellschaft. In: Gesammelte Schriften. Frankfurt am Main: Suhrkamp, 1986. $20 \mathrm{v}$.

. (Fr). Freizeit. In: Gesammelte Schriften. Frankfurt am Main: Suhrkamp, 1986. 20 V.

. (EnA). Erziehung nach Auschwitz. In: Gesammelte Schriften. Frankfurt am Main: Suhrkamp, 1986. $20 \mathrm{v}$.

. (MM). Minima moralia. Tradução de Luiz Eduardo Bicca. Revisão de Guido de Almeida. São Paulo: Ática, 1992.

. (PETG). Philosophische Elementer einer Theorie der Gesellschaft. Frankfurt am Main: Suhrkamp, 2008.

. (DN). Dialética negativa. Tradução de M. A. Casanova. Revisão de E. S. Neves Silva. Rio de Janeiro: Zahar, 2009.

COHN, G. Introdução: Adorno e a teoria crítica da sociedade. In: COHN, G. (Ed.). Theodor W. Adorno: sociologia. São Paulo: Ática, 1986.

EAGLETON, T. A ideologia da estética. Tradução de Mauro Sá Rego Costa. Rio de Janeiro: Jorge Zahar, 1993.

. Ideologia: uma introdução. Tradução de S. Vieira e L. C. Borges. São Paulo: Editora UNESP; Boitempo, 1997.

FLECK, A. Theodor W. Adorno: um crítico na era dourada do capitalismo. 2015. Tese (Doutorado) - Programa de Pós-Graduação em Filosofia, UFSC, Florianópolis, 2015. 
FREYENHAGEN, F. Adorno's politics: theory and praxis in Germany's 1960s. Philosophy and Social Criticism, v. 40, n. 9, p. 867-893, 2014.

HEGEL, G. W. F. Enciclopédia das ciências filosóficas. I - A ciência da lógica. Tradução de Paulo Meneses. São Paulo: Loyola, 1995.

HONNETH, A. The critique of power: reflective stages in a critical social theory. Tradução de Kenneth Baynes. Cambridge: MIT Press, 1993.

HORKHEIMER, M. Teoria tradicional e teoria crítica. In: BENJAMIN, W.; ADORNO, T.; HORKHEIMER, M.; HABERMAS, J. Textos escolhidos. Tradução de José Lino Grünnewald et al. São Paulo: Abril Cultural,1975. p. 125-169.

JUÁREZ, E. A. Th. W. Adorno: el elogio de la teoría y la impaciencia de la praxis. Signos Filosóficos, v. XIV, n. 27, p. 89-118, 2012.

LUKÁCS, G. História e consciência de classe. Tradução de Rodnei Nascimento. São Paulo: Martins Fontes, 2003.

MARX, K. O capital. Livro I. Tradução de R. Barbosa e F. R. Kothe. São Paulo: Nova Cultural, 1985.

PINZANI, A. De objeto de políticas a sujeitos da política: dar voz aos pobres. Ethic@, v. 10, n. 3, p. 83-101, 2011.

RENAULT, E. The political philosophy of social suffering. In: BRUIN, B.; ZURN, C. New waves in political philosophy. Hampshire: Palgrave Macmillan, 2009. p. 158-176.

WIGGERSHAUS, R. The Frankfurt school: its history, theories, and political significance. Tradução de Michael Robertson. Cambridge: MIT Press, 1995.

ZUIDERVAART, L. Social philosophy after Adorno. Cambridge: Cambridge University Press, 2007.

. Theodor W. Adorno. In: ZALTA, E. (Ed.). The Stanford Encyclopedia of Philosophy. Winter Edition. 2011. Disponível em: <http://plato.stanford.edu/archives/ win2011/entries/adorno/>. Acesso em: 30 nov. 2011.

Recebido: 2016-09-29

Aceito: 2017-05-08 
FLECK, A. 